\title{
THE STRATEGIC IMPORTANCE OF MOTIVATIONAL REWARDS FOR LOWER-LEVEL EMPLOYEES IN THE MANUFACTURING AND RETAILING INDUSTRIES
}

\author{
CA ARNOLDS \\ cecil.arnolds@nmmu.ac.za \\ Department of Business Management \\ Nelson Mandela Metropolitan University \\ DJL VENTER \\ Department of Statistics \\ Nelson Mandela Metropolitan University
}

\begin{abstract}
One of the biggest challenges that managers face in executing business strategies to achieve competitive advantage, is the employment of motivational techniques that build wholehearted commitment to operating excellence. Much confusion however still exists on the question of which rewards really motivate employees. This study investigates which rewards motivate lower-level employees $(\mathrm{N}=367)$ in both manufacturing and clothing retail firms. The results show that the most important individual motivational reward for blue-collar employees is paid holidays and for frontline employees, retirement plans. The most important motivational reward category for both blue-collar and frontline employees is fringe benefits (paid holidays, sick leave and housing loans).
\end{abstract}

Key words: Compensation, employee benefits, job design, motivation, rewards

The very competitive business environment places huge demands on modern-day managers. These demands include keeping pace with ever-advancing technology, incorporating the Internet and e-commerce into strategies and business models, understanding the challenges of globalisation, cutting back personnel and resources, managing workforce diversity, balancing work with family concerns, managing the conflicting demands of employees and exploring new ways of working such as virtual teams and telecommuting (Daft, 2006).

According to Bateman and Snell (2007), the fundamental success drivers for competitive advantage for businesses are innovation (introducing new goods and services to adapt to changes in consumer demand and the challenges of new competitors); quality (excellence of product, services and processes); speed (fast and timely execution, response and delivery of results); and cost competitiveness (keeping cost low by applying the principles of effectiveness and efficiency). None of the above-mentioned demands and success drivers can be successfully addressed and implemented, respectively, without highly skilled managers motivating their subordinates to achieve these objectives.

Motivation is fundamental to employee behaviour, such as loyalty, good citizenship and job performance at high output and high quality levels (Bateman \& Snell, 2007). Motivation is defined as those internal and/or external forces that trigger actions that persist until a certain goal is achieved (Daft, 2006). In business firms, these triggers of behaviour are various needs that employees are striving to satisfy through various intrinsic and extrinsic rewards they receive at work (Bateman \& Snell, 2007; George \& Jones, 2006). Examples of intrinsic rewards are feelings of achievement and personal growth, while extrinsic rewards include outcomes such as salary, status, job security and fringe benefits (Hellriegel et al., 2004).

One of the biggest challenges that managers face in executing business strategies to achieve competitive advantage, is the selection and employment of motivational techniques or rewards that build wholehearted commitment to operating excellence and winning attitudes among employees (Thompson, Strickland \& Gamble, 2005). Thompson et al. (2005) suggest that a properly designed reward structure is management's most powerful tool for mobilising organisational commitment to successful strategy execution.

Despite the need for higher levels of employee motivation, surveys show that there is a huge crisis of motivation in most large corporations (Burton, 2001; Dixon, 2004). Business firms spend billions of rands each year on courses, incentives and measuring tools to increase employee motivation, but these interventions do not always translate into higher levels of employee motivation (Burton, 2001; Dixon, 2004).

It is suggested that the reason for this state of affairs is that managers simply do not understand the subject of motivation and therefore fail to motivate their workforce (Birkin, 2004; Grimes, 2005). Others suggest that management's failure to achieve increased employee motivation could be located in the differences of perceptions between management and their subordinates of the way organizational goals need to be achieved (Birkin, 2004; Delany \& Turvey, 2004). Management, for instance, strives for the growth of their firms, while employees strive to grow with their firms (Birkin, 2004). Management wants to achieve their formulated strategies, while employees want to understand their role in achieving these strategies (Birkin, 2004). Delany and Turvey (2004) suggest that managers want a "Just-in-Time" workforce, creativity with speed, high productivity and morale, employee retention, pay-for-performance, a low promise of job security, adaptability to change and protection of employer intellectual capital. Employees, on the other hand, want an entrepreneurial environment, strong skill development and opportunities, high visibility in the organisation, career mentoring, more discretion in job creation, work-life-balance, flexibility, competitive compensation and benefits, and recognition for their unique contributions (Delany \& Turvey, 2004).

Further to the above review, there is still much confusion about which rewards really motivate employees. Meta-analyses of research on motivation have, for example, shown that managers still view money as the main motivator of employees, despite the lack of conclusive evidence on the motivational impact of monetary rewards on the job performance of employees (Why money is not a motivator, 2004). These analyses also report that people never rate money as their main motivator, that most achievements are reached for reasons other than money, that money is a factor that attracts people but does not play a big role in retaining and motivating them, and that the largest workforce in the world is made up of volunteer workers who do not do the work for the money (Why money is not a motivator, 2004).

Barrier (1996) holds the view that showing appreciation, in other words recognising performance, is a stronger motivator of performance than monetary incentives. Tiglao-Torres 
(1990) concurs that frontline employees rate recognition rewards higher than financial rewards, while Anderson Consulting recommended that performance bonuses should be "augmented" with various recognition rewards to maximize the motivational impact (People really do make the difference, 2002). It has also been suggested that blue-collar employees are more concerned about job security than monetary rewards (Smith \& Tisak, 1993).

The question is therefore which rewards are the real motivators of job performance. From a strategic management perspective, it is important to design the most effective reward structure for firms, because the implementation of a firm's business strategy depends on it.

Concurring with Thompson et al. (2005), the present study seeks to identify the rewards which best motivate employees. In doing so the study also addresses the concern expressed by Igalens and Roussel (1999) that the assumptions that underpin the compensation policies of human resource managers have not been adequately and conclusively tested by field research. The primary objective of the study, therefore, is to determine the importance of motivational rewards as perceived by lowerlevel employees in both manufacturing and clothing retail firms. For the purposes of this study, lower-level employees are defined as that layer of employees that Hellriegel et al. (2004) label as non-managers. They include blue-collar workers, such as machine operators, process controllers and technicians, and frontline workers, such as service attendants, drivers, cleaners and sales personnel.

\section{LITERATURE OVERVIEW}

As indicated above, there is still much confusion about which rewards really motivate employees. In particular, the question of finding the right mix of financial (extrinsic) and non-financial (intrinsic) rewards has been troubling human resource managers (Samodien, 2004).

Luthans (1998) distinguishes between two types of rewards, namely financial and non-financial (social, consumable, visual and auditory, manipulatable and job design) rewards. Following a discussion of this distinction, the confusion about the motivational power of selected rewards is reviewed.

\section{Financial rewards}

It has been reported that, while direct financial rewards play a critical role in attracting talented employees, they have only a short-term impact on the motivational levels of employees (Ellis $\&$ Pennington, 2004; Samodien, 2004). It has also been shown that financial incentives, though widely used as motivators, create other problems, such as employees trying to get their work done quickly without concern for quality (How can you increase employee motivation?, 2005).

Evidence has been produced that indicates that a financial reward such as profit-sharing does not encourage motivation in all employees (How can you increase employee motivation?, 2005). Shives and Scott (2003) and DuBrin (1997) however reported that gainsharing improved the productivity of employees. Gainsharing is an approach to enhance organisational effectiveness which embraces the whole firm through a formal system of employee involvement and financial bonuses based on productivity gains. It is mainly focused on reducing costs, which results in a monthly payment of bonuses. Profit-sharing, on the other hand, is not that specific in indicating exactly what each employee must do on a daily basis to improve profitability. Profit-sharing bonuses are paid out on an annual basis and employees often believe that managers will not keep their promises in paying out the profit bonuses (Gainsharing, 1997). Profit bonuses are also perceived to focus only on higher-level employees and not on lower-level employees
(Gainsharing, 1997). Employees further feel that profit-sharing does not provide for individual performance (Bateman and Snell, 2007) and that they (the employees) have little influence on the overall profitability of the business (Hellriegel, Slocum \& Woodman, 2001).

Many managers still view money as the main motivator of employees, despite the lack of conclusive evidence about the motivational impact of monetary rewards on the job performance of employees (Why money is not a motivator, 2004). Van Zyl (2000) and Sherrat (2000) concur that a bonus or $13^{\text {th }}$ cheque is no longer a consideration among employees to increase their job performance or remain with a firm.

It has also been reported that business firms are increasingly providing financial rewards, such as childcare and educational support programmes and that these financial rewards are effective in attracting and retaining staff (Burton, 2001; De Leiburne, 1991). Barrier (1996), however, suggested that recognition or showing appreciation, which is a social reward, is a stronger motivator of performance than monetary incentives (Barrier, 1996). It is therefore proposed that:

P1: Financial rewards are important motivators of the job performance of lower-level employees, but are not more important than social rewards.

\section{Social rewards}

Groenewald (2004) is of the view that managers' prime focus on the bottom line and task achievement at the expense of a social orientation that fosters positive attitudes among employees is often the cause of lower productivity. Many research findings have, for example, revealed that recognition or showing appreciation for work done, which is a social reward, is a stronger motivator of performance than financial rewards (Barrier, 1996).

Management consultants concur that the business firms which excel at service and sales are those that invest a considerable amount of time, energy and resources in providing for the social rewards of their employees (Freemantle, 2004). Empirical research stretching over thirty years has consistently shown that the social interaction with colleagues, their acceptance and approval are important determinants of employee productivity (Seigel \& Ruh, 1973; Smith \& Tisak, 1993, Stajkovic \& Luthans, 2001). Alfred (1991), for example, reported that one of the needs employees expressed the most was the need to be accepted. According to Kemp (2002), however, managers declare in mission statements that people are their most valued asset, and then fail to practise this philosophy.

Against the background of the preceding literature review, social rewards should be the strongest motivator of employee job performance. It is therefore proposed that:

P2: Social rewards are the most important motivators of the job performance of lower-level employees.

\section{Job design rewards}

Managers often use job design rewards to increase employees' work efficiency and productivity (Certo, 2003). According to Luthans (1998), these rewards include adding more responsibility to the job, allowing more autonomy on the job, providing job security, job rotation, employee involvement in decision making, career planning and development, and flexitime.

Research findings and business practice experience seem to support the importance of job design rewards as motivators of employee job performance. Burton (2001), for instance, reported that involving employees in setting their own objectives and allowing them to participate in decision making lead to increased employee motivation. Kauermann and Ortlieb (2004) showed that job insecurity leads to reduced employee motivation and increased absenteeism. Malherbe and Pearse (2003) found that employee motivation is enhanced by changing 
core aspects of a job, such as adding more responsibility, allowing more autonomy and providing for career development. It is consequently proposed that:

P3: Job design rewards are important motivators of the job performance of lower-level employees, but are not more important than social and financial rewards.

\section{Consumable rewards}

Luthans (1998) reported that consumable rewards, such as coffee break treats, free or subsidised lunches, company picnics, dinners for employees' families paid for by the firm, and afterwork cheese and wine parties, are often used by firms to motivate their employees. Arnolds and Boshoff (2002) found that South African human resource managers do not rate consumable rewards very highly as motivators of lower-level employees. An American survey of 612 employees of all organisational levels (Workplace changes employees want to see, 1999) and a study by Hong, Yang, Wang, Chiou, Sun and Huang (1995) also did not show consumable rewards as important motivators of employee job performance. It is therefore proposed that:

P4: Consumable rewards are the least important motivators of the job performance of lower-level employees.

\section{Manipulatable rewards}

According to Luthans (1998), manipulatable rewards include jewellery (watches, rings or tie pins), clothing (uniform of firm), commendations (recommending for promotion and other employment), company cars, on-site fitness services and the use of company recreation/convenience facilities for personal projects. There is some evidence that jewellery and certain types of clothing (for example, T-shirts) and crockery appeal to employees' need for recognition, and might therefore motivate some employees (DuBrin, 1997). Sherrat (2000) reported that relaxed dress codes have become an important non-monetary reward in South African firms. Arnolds and Boshoff (2002) found that South African human resource managers rate company cars as one of the main motivators of lower-level employees. It is therefore proposed that

P5: Manipulatable rewards are important motivators of the job performance of lower-level employees, but are not more important than social, financial and job design rewards

\section{Visual and auditory rewards}

Visual and auditory rewards refer to the use of music and visual images to make the working conditions of employees pleasant. This is often done through piped-in music at employees' workstations, motivational posters and company literature, such as newsletters or magazines. Despite research findings that music in the workplace can result in increased employee morale and productivity, especially in job situations that are characterised by high repetition and tension (Listening to music increases productivity, 2005), Arnolds and Boshoff (2002) found that human resource managers do not regard piped-in music at employees' workstations as an important motivational reward for lower-level employees.

Luthans (1998) suggests that the provision of free company literature keeps employees informed about important happenings, achievements, issues and decisions of their firms. This could satisfy the belonging and sense of importance needs of employees and has thus the potential to motivate employees. Arnolds and Boshoff (2002), however, reported that human resource managers do not regard free company literature as an important motivational reward in South African firms. It is therefore proposed that:

P6: Visual and auditory rewards are not important motivators of job performance of lower-level employees, but are more important than consumable rewards

By investigating the above-mentioned propositions, the present study seeks to address the challenge of finding sustainable ways to motivate lower-level employees. By doing so, the study will speak to Kemp's (2002) assertion that lower employee productivity, through active disengagement, is not always the result of the lack of a work ethic among workers, but possibly the inability of managers to manage their human resources properly. The study will then also respond to McFarlin's (2000) concern that managers often focus too much on what might get employees moving (in other words, emphasis on financial rewards), rather than thinking about how to keep them moving in the right direction once they have started (sustained motivation).

\section{RESEARCH DESIGN}

\section{Research approach}

In the world of science, two main approaches to research are distinguished, namely the positivistic and the phenomenological approaches (Collis \& Hussey, 2003). The positivistic or quantitative approach attempts to explain social phenomena by establishing a relation between variables. These variables are presented as information converted into numbers. To put it somewhat differently: by assigning numeric values to observed phenomena and counting the frequency of those phenomena, some conclusions about the characteristics of the populations may be inferred (Collis \& Hussey, 2003). In terms of the quantitative approach, clearly constructed hypotheses are formulated about the relationship between two or more variables. Data about these variables are collected through methods such as questionnaires, focus groups, interviews, case studies and experiments. The relationships between the variables are measured by means of statistical methods such as multiple regression analysis, structural equation analysis and the Pearson product-moment correlational analysis (Struwig \& Stead, 2001).

The phenomenological or qualitative research paradigm suggests that social reality is within the unit of research, and that the act of investigating the reality has an effect on that reality. This paradigm pays considerable attention to the subjective state of the individual. Researchers applying the phenomenological approach focus on the meaning rather than the measurement of social problems (Collis \& Hussey, 2003). Qualitative research concerns itself with approaches such as ecological psychology, symbolic interactionism and postmodernism and employs statistical methods, such as observation, archival source analysis, interviews, focus groups and content analysis (Struwig \& Stead, 2001).

The present study seeks to quantify the importance of a variable in a given relationship, for example, the importance of financial rewards in their relationship to employee job performance. Although the relationship as such between the variables included in this study is not empirically measured, the quantified importance of the independent variable indicates the degree of influence the respondents perceive this variable to be exerting on the independent variable. As the aim was to quantify the importance of the motivational rewards in their influencing of employee job performance, the positivistic or quantitative approach was chosen.

\section{Research method \\ Participants}

Convenience sampling was used to select a sample of 367 lower-level employees drawn from 22 business firms in the Nelson Mandela Metropolitan Municipality. Of these, 213 were blue-collar workers and 154 were frontline (service) employees. The blue-collar employee sample included machine operators, process controllers, machine service attendants, technicians, drivers and cleaners, while the frontline employee sample included service centre operators, sales assistants, receptionists and security personnel. The blue-collar employee sample consisted of $52 \%$ males, while the frontline employee sample consisted of $68.2 \%$ females. 


\section{Data collection}

To measure the latent variables defining the motivational rewards construct based on Luthans's (1998) categorisation of rewards, a structured questionnaire was used. It included a list of 46 types of rewards (see annexure A) that are generally used in business firms. The list was prefaced with the question, "To what extent do you regard the following rewards as important motivators of your job performance?". Responses were anchored by a 5-point Likert (1961) scale ranging from $1=$ Not at all important to $5=$ A great deal important .

Questionnaires were distributed by well-trained contact persons. The confidentiality and anonymity of all respondents were strictly guaranteed.

\section{Data analysis}

The BMDP4M statistical software package (Frane, Jennrich \& Sampson, 1990) was utilised to:

- Calculate Cronbach's alpha coefficients to determine the internal consistency of the initial construct based on Luthans's (1998) categorisation and the revised construct derived from exploratory factor analysis;

- conduct exploratory factor analysis to determine the discriminant validity of the initial construct and to generate a revised construct with improved discriminant validity. All the data were combined for the factor analysis, but the calculation of scores and their ranking were conducted separately for the blue-collar and frontline workers. The method of principal component analysis with direct quartimin rotation was deemed most appropriate for the observed data;

- and calculate descriptive statistics for the 46 items and the summated scores for the latent variables in the initial and revised construct.

MS-Excel (2003) was used to calculate the practical significance statistics on which the ranking of items and summated scores was based. Inferential statistics were not required due to the exploratory nature of this study. No hypotheses were therefore postulated.

\section{RESULTS}

\section{Internal consistency}

The first step in the data analysis process was to assess the internal consistency of the initial construct based on Luthans's (1998) categorisation. The results reported in Table 1 show that all the summated scores relating to the initial construct obtained Cronbach alpha values greater or equal to 0.80 , substantially higher than the 0.70 minimum recommended by Nunnally (1978). The scores derived from the instrument relating to the initial construct were therefore found to be highly reliable.

TABLE 1

INTERNAL CONSISTENCY OF INITIAL CONSTRUCT BASED ON LUTHANS'S CATEGORISATION (1998)

\begin{tabular}{llc}
\hline Factor & Items & Cronbach's alpha \\
\hline Financial rewards & Finan1 to Finan18 & 0.96 \\
Consumable rewards & Consu1 to Consu5 & 0.90 \\
Manipulatable rewards & Manip1 to Manip6 & 0.86 \\
Visual and auditory rewards & Visua1 and Visua2 & 0.80 \\
Social rewards & Socia1 to Socia6 & 0.95 \\
Job design rewards & Jobde1 to Jobde9 & 0.92 \\
\hline
\end{tabular}

\section{Discriminant validity}

The second phase of the data analysis consisted of exploratory factor analysis to obtain a motivational rewards construct with acceptable discriminant validity. This was important as some workers could for instance have regarded company cars as financial rewards, while others might have followed Luthans's (1998) proposal in classifying company cars as manipulatable rewards. Another reason why it was important to determine how workers view these rewards, was that wrong conclusions could be drawn on the importance of rewards as a category (for instance, are financial rewards more motivational than social rewards) if this analysis were not done.

Utilising the BMDP4M computer program (Frane, Jennrich \& Sampson, 1990) for exploratory factor analysis, it was found that the initial construct lacked discriminant validity. A revised construct with acceptable discriminant validity was derived by means of an iterative series of factor analyses during which items that loaded significantly on two or more factors or that did not load significantly on any factor were omitted from the factor structure. The process concluded with a construct consisting of five factors as opposed to the six factor structure proposed by Luthans (1998). Statistics relating to the final factor structure and internal consistency of the revised construct are summarised in Table 2. The factors were labelled to reflect the nature of the reward associated with the relevant items.

TABle 2

STATISTICS RELATING TO THE FACTROS STRUCTURE AND INTERNAL CONSISTENCY OF THE REVISED MOTIVATIONAL REWARDS CONSTRUCT

\begin{tabular}{|c|c|c|c|c|c|}
\hline \multicolumn{6}{|c|}{ Factor Loadings } \\
\hline & $\begin{array}{l}\text { Factor } 1 \\
\text { Direct } \\
\text { Financial } \\
\text { Rewards }\end{array}$ & $\begin{array}{c}\text { Factor } 2 \\
\text { Social } \\
\text { Rewards }\end{array}$ & $\begin{array}{c}\text { Factor } 3 \\
\text { Consumable } \\
\text { Rewards }\end{array}$ & $\begin{array}{l}\text { Factor } 4 \\
\text { Job Design } \\
\text { Rewards }\end{array}$ & $\begin{array}{c}\text { Factor 5 } \\
\text { Indirect } \\
\text { Financial } \\
\text { Rewards }\end{array}$ \\
\hline FINAN4 & 0.841 & - & - & - & - \\
\hline FINAN5 & 0.828 & - & - & - & - \\
\hline FINAN3 & 0.808 & - & - & - & - \\
\hline FINAN7 & 0.698 & - & - & - & - \\
\hline FINAN2 & 0.685 & - & - & - & - \\
\hline FINAN8 & 0.614 & - & - & - & - \\
\hline FINAN1 & 0.607 & - & - & - & - \\
\hline FINAN10 & 0.592 & - & - & - & - \\
\hline FINAN6 & 0.582 & - & - & - & $0.440^{*}$ \\
\hline FINAN11 & 0.567 & - & - & - & - \\
\hline SOCIA1 & - & 0.874 & - & - & - \\
\hline SOCIA2 & - & 0.832 & - & - & - \\
\hline SOCIA4 & - & 0.800 & - & - & - \\
\hline SOCIA6 & - & 0.734 & - & - & - \\
\hline SOCIA3 & - & 0.718 & - & - & - \\
\hline SOCIA5 & - & 0.637 & - & - & - \\
\hline JOBDE6 & - & 0.521 & - & - & - \\
\hline JOBDE7 & - & 0.487 & - & - & - \\
\hline JOBDE1 & - & 0.482 & - & - & - \\
\hline CONSU5 & - & - & 0.812 & - & - \\
\hline CONSU3 & - & - & 0.759 & - & - \\
\hline MANIP2 & - & - & 0.714 & - & - \\
\hline FINAN18 & - & - & 0.622 & - & - \\
\hline CONSU4 & - & - & 0.606 & - & - \\
\hline MANIP4 & - & - & 0.517 & - & - \\
\hline CONSU2 & - & - & 0.510 & - & - \\
\hline FINAN17 & - & - & 0.364 & - & - \\
\hline JOBDE5 & - & - & - & 0.894 & - \\
\hline JOBDE4 & - & - & - & 0.877 & - \\
\hline JOBDE3 & - & $0.454^{*}$ & - & 0.527 & - \\
\hline FINAN14 & - & - & - & - & 0.811 \\
\hline FINAN13 & - & - & - & - & 0.712 \\
\hline FINAN15 & - & - & - & - & 0.477 \\
\hline Eigen values & 18.89 & 1.92 & 1.54 & 1.20 & 0.941 \\
\hline Cum.\% variance & 57.2 & 63.1 & 67.7 & 71.4 & 74.2 \\
\hline \multicolumn{6}{|l|}{ Cronbach's alpha: } \\
\hline All data combined & 0.96 & 0.95 & 0.92 & 0.89 & 0.83 \\
\hline Blue-collar workers & s $\quad 0.96$ & 0.95 & 0.91 & 0.82 & 0.81 \\
\hline Frontline workers & 0.94 & 0.95 & 0.92 & 0.87 & 0.86 \\
\hline
\end{tabular}

1) Loadings less than 0.30 were considered insignificant and omitted from the table for readability.

2) Items FINAN6 and JOBDE3 were retained as the loading on the secondary factor (indicated by *) was significantly smaller than the loading on the primary factor. 
Ranking of motivational rewards

The third step in the data analysis involved the calculation of statistics to rank both the individual reward items and the derived reward factors to determine their relative importance as perceived by lower-level employees. Ranking was a two-stage process:

1. Rewards were first sorted in descending sequence on the sample mean values of the summated scores.

2. To reflect the practical significance of the differences between consecutive rewards in the sorted list, Cohen's d-statistics (1988) were calculated to group rewards together in one ranking level based on the principle that Cohen's d-statistics (1988) less than 0.20 are deemed insignificant. The rewards were sorted according to these practical significance rankings.
Before the ranking statistics could be calculated, the propositions to be tested for the study had to be reformulated, because of the substantive difference between the initial and revised models. In the factor analysis, visual and auditory, and manipulatable rewards did not emerge as distinct and separate factors, while financial rewards split into two factors, namely direct and indirect financial rewards. The propositions were revised as follows:

P1: Direct financial rewards (direct pay, incentives and benefits) are important motivators of the job performance of lower-level employees, but not more important than social rewards.

P2: Indirect financial rewards (fringe benefits) are important motivators of the job performance of lower-level employees, but not more important than social rewards and direct financial rewards.

TABLE 3

INDIVIDUAL REWARD ITEMS RANKED IN PRACTICAL SIGNIFICANCE ORDER (RP)

\begin{tabular}{|c|c|c|c|c|c|c|c|c|c|c|c|c|c|}
\hline \multirow[b]{2}{*}{ Item } & \multicolumn{6}{|c|}{ Sorted list for Blue-Collar Workers $(n=213)$} & \multicolumn{7}{|c|}{ Sorted list for Frontline Workers $(n=154)$} \\
\hline & $\begin{array}{l}\text { Blue-collar } \\
\text { Mean }\end{array}$ & $\mathrm{Rp}$ & $\begin{array}{l}\text { Frontline } \\
\text { Mean }\end{array}$ & $\mathrm{Rp}$ & $\begin{array}{c}\text { Difference } \\
\text { Mean }\end{array}$ & Rp & Item & $\begin{array}{l}\text { Frontline } \\
\text { Mean }\end{array}$ & $\mathrm{Rp}$ & $\begin{array}{l}\text { Blue-collar } \\
\text { Mean }\end{array}$ & Rp & $\begin{array}{c}\text { Difference } \\
\text { Mean }\end{array}$ & $\mathrm{Rp}$ \\
\hline Finan14 & 4.12 & 1 & 4.39 & 1 & -0.27 & 0 & Finan8 & 4.50 & 1 & 3.51 & 5 & 0.99 & -9 \\
\hline Jobde1 & 3.88 & 2 & 4.19 & 3 & -0.31 & -7 & Finan2 & 4.47 & 1 & 3.41 & 5 & 1.06 & -9 \\
\hline Finan1 & 3.85 & 2 & 4.42 & 1 & -0.57 & 1 & Finan1 & 4.42 & 1 & 3.85 & 2 & 0.57 & -1 \\
\hline Finan13 & 3.77 & 3 & 4.31 & 2 & -0.54 & -2 & Jobde9 & 4.41 & 1 & 3.65 & 4 & 0.76 & -6 \\
\hline Socia1 & 3.73 & 3 & 4.19 & 3 & -0.46 & -5 & Finan14 & 4.39 & 1 & 4.12 & 1 & 0.27 & 0 \\
\hline Finan6 & 3.67 & 3 & 4.23 & 3 & -0.56 & -5 & Socia4 & 4.33 & 2 & 3.54 & 4 & 0.79 & -1 \\
\hline Jobde9 & 3.65 & 4 & 4.41 & 1 & -0.76 & 6 & Finan13 & 4.31 & 2 & 3.77 & 3 & 0.54 & 2 \\
\hline Manip6 & 3.64 & 4 & 3.97 & 5 & -0.33 & -14 & Socia2 & 4.28 & 2 & 3.37 & 5 & 0.91 & -4 \\
\hline Socia4 & 3.54 & 4 & 4.33 & 2 & -0.79 & 1 & Finan11 & 4.25 & 3 & 3.51 & 5 & 0.74 & -1 \\
\hline Finan8 & 3.51 & 5 & 4.50 & 1 & -0.99 & 9 & Finan6 & 4.23 & 3 & 3.67 & 3 & 0.56 & 5 \\
\hline Finan11 & 3.51 & 5 & 4.25 & 3 & -0.74 & 1 & Jobde1 & 4.19 & 3 & 3.88 & 2 & 0.31 & 7 \\
\hline Finan9 & 3.47 & 5 & 3.77 & 6 & -0.30 & -18 & Socia1 & 4.19 & 3 & 3.73 & 3 & 0.46 & 5 \\
\hline Finan2 & 3.41 & 5 & 4.47 & 1 & -1.06 & 9 & Socia6 & 4.19 & 3 & 3.20 & 7 & 0.99 & -12 \\
\hline Finan15 & 3.40 & 5 & 4.04 & 4 & -0.64 & -7 & Socia3 & 4.18 & 3 & 3.28 & 6 & 0.90 & -9 \\
\hline Finan7 & 3.39 & 5 & 4.00 & 5 & -0.61 & -11 & Finan5 & 4.16 & 3 & 3.03 & 8 & 1.13 & -16 \\
\hline Socia2 & 3.37 & 5 & 4.28 & 2 & -0.91 & 4 & Socia5 & 4.15 & 3 & 3.11 & 7 & 1.04 & -12 \\
\hline Jobde2 & 3.37 & 5 & 3.45 & 9 & -0.08 & -25 & Jobde8 & 4.08 & 4 & 3.31 & 6 & 0.77 & -1 \\
\hline Finan12 & 3.35 & 6 & 3.93 & 5 & -0.58 & -3 & Finan18 & 4.06 & 4 & 2.54 & 11 & 1.52 & -19 \\
\hline Jobde8 & 3.31 & 6 & 4.08 & 4 & -0.77 & 1 & Finan15 & 4.04 & 4 & 3.40 & 5 & 0.64 & 7 \\
\hline Socia3 & 3.28 & 6 & 4.18 & 3 & -0.90 & 9 & Finan3 & 4.01 & 4 & 2.91 & 9 & 1.10 & -15 \\
\hline Socia6 & 3.20 & 7 & 4.19 & 3 & -0.99 & 12 & Finan7 & 4.00 & 5 & 3.39 & 5 & 0.61 & 11 \\
\hline Manip3 & 3.18 & 7 & 3.94 & 5 & -0.76 & 0 & Finan4 & 3.99 & 5 & 2.93 & 8 & 1.06 & -4 \\
\hline Socia5 & 3.11 & 7 & 4.15 & 3 & -1.04 & 12 & Manip6 & 3.97 & 5 & 3.64 & 4 & 0.33 & 14 \\
\hline Consu1 & 3.08 & 7 & 3.81 & 6 & -0.73 & -7 & Jobde6 & 3.96 & 5 & 3.06 & 8 & 0.90 & -4 \\
\hline Jobde6 & 3.06 & 8 & 3.96 & 5 & -0.90 & 4 & Jobde7 & 3.95 & 5 & 2.92 & 8 & 1.03 & -4 \\
\hline Finan17 & 3.06 & 8 & 3.74 & 7 & -0.68 & -5 & Manip3 & 3.94 & 5 & 3.18 & 7 & 0.76 & 0 \\
\hline Jobde3 & 3.06 & 8 & 3.56 & 8 & -0.50 & -8 & Finan12 & 3.93 & 5 & 3.35 & 6 & 0.58 & 3 \\
\hline Finan5 & 3.03 & 8 & 4.16 & 3 & -1.13 & 16 & Consu1 & 3.81 & 6 & 3.08 & 7 & 0.73 & 7 \\
\hline Finan10 & 2.96 & 8 & 3.64 & 7 & -0.68 & -5 & Finan9 & 3.77 & 6 & 3.47 & 5 & 0.30 & 18 \\
\hline Finan4 & 2.93 & 8 & 3.99 & 5 & -1.06 & 4 & Finan17 & 3.74 & 7 & 3.06 & 8 & 0.68 & 5 \\
\hline Jobde7 & 2.92 & 8 & 3.95 & 5 & -1.03 & 4 & Finan16 & 3.66 & 7 & 2.49 & 11 & 1.17 & -6 \\
\hline Finan3 & 2.91 & 9 & 4.01 & 4 & -1.10 & 15 & Finan10 & 3.64 & 7 & 2.96 & 8 & 0.68 & 5 \\
\hline Manip1 & 2.89 & 9 & 3.21 & 11 & -0.32 & -7 & Consu2 & 3.59 & 8 & 2.64 & 10 & 0.95 & -1 \\
\hline Manip5 & 2.66 & 10 & 3.03 & 12 & -0.37 & -9 & Jobde3 & 3.56 & 8 & 3.06 & 8 & 0.50 & 8 \\
\hline Consu2 & 2.64 & 10 & 3.59 & 8 & -0.95 & 1 & Jobde2 & 3.45 & 9 & 3.37 & 5 & 0.08 & 25 \\
\hline Manip4 & 2.61 & 11 & 3.29 & 10 & -0.68 & 0 & Jobde5 & 3.36 & 10 & 2.46 & 12 & 0.90 & -4 \\
\hline Finan18 & 2.54 & 11 & 4.06 & 4 & -1.52 & 19 & Manip4 & 3.29 & 10 & 2.61 & 11 & 0.68 & 0 \\
\hline Finan16 & 2.49 & 11 & 3.66 & 7 & -1.17 & 6 & Consu4 & 3.27 & 10 & 2.41 & 12 & 0.86 & -4 \\
\hline Visau2 & 2.48 & 11 & 3.01 & 13 & -0.53 & -8 & Manip1 & 3.21 & 11 & 2.89 & 9 & 0.32 & 7 \\
\hline Jobde5 & 2.46 & 12 & 3.36 & 10 & -0.90 & 4 & Consu3 & 3.18 & 11 & 2.22 & 13 & 0.96 & -3 \\
\hline Consu4 & 2.41 & 12 & 3.27 & 10 & -0.86 & 4 & Consu5 & 3.16 & 11 & 1.86 & 14 & 1.30 & -7 \\
\hline Jobde4 & 2.31 & 13 & 3.14 & 11 & -0.83 & 3 & Jobde4 & 3.14 & 11 & 2.31 & 13 & 0.83 & -3 \\
\hline Manip2 & 2.29 & 13 & 3.01 & 13 & -0.72 & -2 & Manip5 & 3.03 & 12 & 2.66 & 10 & 0.37 & 9 \\
\hline Visau1 & 2.25 & 13 & 2.89 & 13 & -0.64 & -2 & Visau2 & 3.01 & 13 & 2.48 & 11 & 0.53 & 8 \\
\hline Consu3 & 2.22 & 13 & 3.18 & 11 & -0.96 & 3 & Manip2 & 3.01 & 13 & 2.29 & 13 & 0.72 & 2 \\
\hline Consu5 & 1.86 & 14 & 3.16 & 11 & -1.30 & 7 & Visau1 & 2.89 & 13 & 2.25 & 13 & 0.64 & \\
\hline
\end{tabular}


TABLE 4

REWARD FACTORS RANKED IN PRACTICAL SIGNIFICANCE ORDER (RP)

\begin{tabular}{|c|c|c|c|c|c|c|c|c|c|c|c|c|c|}
\hline \multirow[b]{3}{*}{ Factor } & \multicolumn{6}{|c|}{ Sorted list for Blue-Collar Workers $(n=213)$} & \multicolumn{7}{|c|}{ Sorted list for Frontline Workers $(n=154)$} \\
\hline & \multicolumn{2}{|c|}{ Blue-Collar } & \multicolumn{2}{|c|}{ Frontline } & \multicolumn{2}{|c|}{ Difference } & \multicolumn{2}{|c|}{ Frontline } & \multicolumn{2}{|c|}{ Blue-Collar } & \multirow[b]{2}{*}{$\mathrm{Rp}$} & \multicolumn{2}{|c|}{ Difference } \\
\hline & Mean & $\mathrm{Rp}$ & Mean & $\mathrm{Rp}$ & Mean & $\mathrm{Rp}$ & Factor & Mean & $\mathrm{Rp}$ & Mean & & Mean & Rp \\
\hline RF5 & 3.77 & 1 & 4.25 & 1 & -0.48 & 0 & RF5 & 4.25 & 1 & 3.77 & 1 & -0.48 & 0 \\
\hline RF2 & 3.34 & 2 & 4.16 & 2 & -0.82 & 0 & RF1 & 4.17 & 2 & 3.32 & 2 & -0.85 & 0 \\
\hline RF1 & 3.32 & 2 & 4.17 & 2 & -0.85 & 0 & RF2 & 4.16 & 2 & 3.34 & 2 & -0.82 & 0 \\
\hline RF4 & 2.61 & 3 & 3.35 & 3 & -0.73 & 0 & $\mathrm{RF} 4$ & 3.35 & 3 & 2.61 & 3 & -0.73 & 0 \\
\hline RF3 & 2.45 & 4 & 3.41 & 3 & -0.96 & 1 & RF3 & 3.41 & 3 & 2.45 & 4 & -0.96 & 1 \\
\hline
\end{tabular}

RF1 = Direct financial rewards, RF2 = Social rewards, RF3 = Consumable rewards, RF4 = Job design rewards, RF5 = Indirect financial rewards

P3: Social rewards (recognition) are the most important motivators of the job performance of lower-level employees.

P4: Job design rewards (autonomy) are important motivators of the job performance of lower-level employees, but not more important than social and financial rewards.

P5: Consumable rewards are the least important motivators of the job performance of lower-level employees.

The empirical results for the individual reward items and the derived reward factors are depicted in Tables 3 and 4 respectively. For comparison purposes the results are presented side by side for the two worker groups and in two sorted lists to make it easier to extract information for a specific low-level worker group.

Table 3 shows that paid holidays are most important reward for blue-collar employees. This is followed by job with more responsibility and wages, which were both ranked second. Despite the Cohen's d coefficients showing no practical significant differences in the importance of the top eight rewards for frontline employees, if forced to make a decision about utilising these rewards for motivational purposes, retirement plans would be ranked first, followed by cash incentives and wages in second and third place respectively.

\section{Most important category of rewards}

To provide a meaningful interpretation of the empirical results which emanated from the analysis to rank the reward categories, it is best to assess these results by using the Cohen's d practical significance ranking. The reason for this is that managers will find it more beneficial to know whether the differences in the importance of rewards per category are practically significant.

Table 4 summarises the empirical results as far as the reward categories are concerned. Indirect financial rewards (RF5 $=$ fringe benefits) were found to be the most important category of rewards for both blue-collar and frontline employees (propositions P2 and P3 not supported). The results show that the social (RF2) and direct financial (RF1 = direct pay, cash incentives, direct benefits) reward categories are both ranked second by both blue-collar and frontline employees (proposition P1 not supported).

Table 4 shows that both blue-collar and frontline employees rank job design rewards (RF4) in the third place. Proposition P4, that job design rewards are not more important than social and financial rewards, is therefore supported. The empirical results also show that consumable rewards (RF3) are the least important motivational rewards for both blue-collar and frontline employees (proposition P5 is supported as far as blue-collar employees are concerned). As far as frontline employees are concerned, however, there is no practical significant difference in the importance of job design (RF4) and consumable rewards (RF3).
The above-mentioned results can be summarised as follows:

- The most important individual motivational reward for bluecollar employees is paid holidays. This is followed by work with more responsibility and wage increases, both ranked in the second place;

- the most important individual motivational rewards for frontline employees are retirement plans, cash incentives, wage increases, job security and paid holidays, all of them ranked in first place;

- the most important motivational reward category for both blue-collar and frontline employees is indirect financial rewards (fringe benefits), followed by social and direct financial rewards (direct pay, cash incentives, direct benefits) in the second place; and

- the least important motivational reward category for both blue-collar and frontline employees is consumable rewards.

\section{DISCUSSION}

The empirical results show that paid holidays were given a number one ranking by both the blue-collar and frontline employees. These results are in agreement with the findings of Hong et al. (1995), which placed paid leave in the top five out of 27 employee benefits. Another form of paid leave, namely sick leave, was given a second ranking by both blue-collar and frontline employees. This suggests that note needs to be taken of paid leave in motivational strategies.

Anecdotal evidence (interview with an employee of a multinational company) suggests that paid holidays have been used successfully as a motivational tool in some firms (Arnolds, 2006). In these firms, employees' performance achievements are "paid" by increasing their holiday leave credits beyond the mandatory limit (Hellriegel et al., 2001). The results of the present study suggest that managers who implement this motivational strategy will definitely reap the benefits in terms of improved employee job performance and morale.

The rationale behind paid leave as a motivational reward emanates from the argument that there is no conclusive link between longer working hours and economic success. For example, long working hours have been reported to have resulted in economic misery in Japan and lower productivity in some European countries. A shorter working week in France, on the other hand, has been reported to increase labour productivity. (Shorter week increases French labour efficiency, 2002.)

Time off from work, albeit through paid holidays or sick leave, satisfies other employee needs as well. It allows employees to spend more time with their families and attend to important matters that have been neglected while employees were working. Paid leave also provides a break from the demands of work with employees returning refreshed to work after leave. Rothbard (2001) demonstrated that providing time off from work to attend to family activities has positive effects on the work engagement of women. Research by May, Gilson and Harter 
(2004) also supported the notion that breaks from work are essential to restore the emotional resources of employees and their engagement with their work. Paid-time-off (PTO) programmes have been shown to reduce unplanned absenteeism and increase employee motivation and morale (Lewis, Goodman $\&$ Fandt, 2004)

The empirical results indicate that wage increases and cash incentives are important motivational rewards for lower-level employees. Previous studies concur with these results, with Hong et al. (1995) and an American survey of 612 employees (Workplace changes employees want to see, 1999) reporting that cash incentives (year-end bonuses and dividends) and salaries, respectively, are among the top five motivational rewards for lower-level employees. It is however important to note that, purely on mean scores (practical significant differences ignored), both blue-collar and frontline employees ranked wage increases in the third place, which suggests that money is not the main motivator of lower-level employees as many managers might have thought. It appears that providing more paid leave benefits and more job responsibility to blue-collar employees, and attending to security need issues, such as retirement plans (linked to job security), for frontline employees, would be a more effective motivational strategy. The notion that money is not the main motivator of job performance among lower-level employees is further supported by the high ranking of friendly managerial greetings (social need) by blue-collar employees.

It could be that the top rating of retirement plans by frontline employees is indicative of the uncertainty that contracts, as opposed to permanent employment relations, are causing among frontline employees. Some of the frontline respondents highlighted this situation on their questionnaires. It will therefore be beneficial for managers in the clothing retail industry to take note of demotivation that contract appointments could be causing in their firms. Wah (1999), for example, reported that managers who do not recognise the value of their contingent workforce are losing out on skills, commitment and loyalty that could ensure their firms' survival. Bratton and Gold (2003) suggest that, instead of taking the "low-road" human resource management (HRM) view of contract employment as a short-term cost-cutting arrangement, which is characterised by low pay, low job security and work intensification, managers should opt for the "high-road" HRM view of high training, high involvement, high rewards and quality commitment. Low-road HRM leads to decreased motivation, innovation and commitment levels among employees, whereas high-road HRM is associated with a positive psychological contract and organisational outcomes.

The empirical results further indicate that blue-collar employees want more responsibility in their job. In other words, employees want their jobs to be enriched with more freedom of decision making, space for creativity, skill variety and task significance. This would increase the meaningfulness of their jobs and result in higher internal work motivation, high-quality work performance, higher job satisfaction and a decrease in absenteeism and staff turnover (Daft \& Marcic, 2007; Hackman \& Oldham, 1980; May et al., 2004). A more enriched job would also decrease the sense of escapism from work which seems to be underlying the demand for paid holidays and sick leave highlighted by the empirical results. It is however often found that additional work responsibility is not a notion generally linked to lowerlevel employees. Managers often create work environments that expect employees to leave their brains at the factory door before taking their places at their assembly lines (Ross, 2001). Such managers fail to reap the benefits of a motivated and engaged employee, as according to Bateman and Snell (2007), very few people respond negatively to job enrichment.

The empirical results also show that, as a group or category, fringe benefits are the most motivational for lower-level employees. This, according to the basic expectancy theory (Vroom, 1964), suggests that these rewards exhibit a higher valence for lower- level employees. In other words, it is possible that lower-level employees regard these fringe benefits (housing loans and paid leave) as important indicators of how their firms value them as employees. It is therefore important for managers to note what message they are sending with the formulation and implementation of fringe benefits.

Based on the Cohen's d practical significance scores, the empirical results reveal that for both the blue-collar and frontline employee groups direct financial rewards (pay, incentives and other direct benefits) with social rewards, and recognition in particular are the best motivators. This is an indication to management that monetary rewards combined with social rewards would deliver better motivational results than monetary compensation alone, which might be the case in many firms. In this regard, it is however important to heed Glassock and Gram's (1995) appeal that monetary rewards should not be confused with recognition. According to Glassock and Gram (1995), monetary rewards are impersonal in nature, geared toward supporting short-term objectives of the firm, based on the corporate budget of the firm, and are infrequently distributed. Recognition, on the other hand, is non-cash and personal in nature and directed at reinforcing behaviours that have the ability to change the organisational culture permanently. Recognition is based on the principles and values of the firm and needs to be dispensed as often as possible.

Glassock and Gram (1995) propose a few techniques for managers to successfully separate monetary compensation from recognition in order to ensure improved motivational effects. In the first place, the words, compensation and recognition, should never be used in the same sentence. Secondly, compensation and recognition must not be facilitated by the same person, team or functional group. Recognition must be dispensed by people knowledgeable in psychology and motivation, while compensation can be distributed by people knowledgeable in finance, accounting and law. Finally, non-monetary awards must be used to create a sincere focus of appreciation. In other words, money must be used purely as a reward linked to compensation. By combining these techniques of recognition with monetary compensation, better results will be achieved as far as the increased motivation (and job performance) is concerned.

Based on the Cohen's d practical significance scores (blue-collar = third ranking; frontline = second ranking), the empirical results show that lower-level employees also want some level of autonomy in their jobs. In other words, lower-level employees also find flexible working hours motivational. To the extent therefore that this can be applied in jobs via teamwork strategies, this could increase motivational levels among lowerlevel employees.

Finally, the results show that rewards which managers generally regard as motivational for employees, such as housing loans, company cars, and profit and gain-sharing plans, do not even feature in the top five individual motivational rewards for lowerlevel employees. This is an indication that the motivational interventions of managers are often misdirected.

\section{CONCLUSION}

This study has shown that it is important that managers take notice of the rewards which their employees find motivational. If this is not done, a mismatch might occur between the strategies managers use to motivate lower-level employees and the motivational rewards these employees actually prefer. This could cause a situation in which employees and managers do not find common ground in the pursuit of organisational objectives. In other words, it is possible that firms fail to successfully implement their business strategies, because the reward systems they use do not agree with the rewards their employees at the operational level find motivating. 
It could be argued that employees of firms should not be the ones dictating the reward systems of firms and that the unhappy employees, who are unproductive, can be easily replaced from an over-supply of employment seekers. Research findings, however, suggest that employees who find themselves in firms in which the reward systems are not aligned to the needs of employees, will perform at the level of what is least expected of them, but will not be motivated to exert the extra effort that makes firms winning enterprises. Such employees will be unhappy, but hooked financially to their firms, while rendering mediocre job performances (Salaries not the only draw card, 2000).

This study concurs with Paul Allaire, former chief executive officer of Xerox Corporation (cited in Thompson et al., 2005, p. 344) that "if you talk change [read, new business objectives] but don't change the reward and recognition system, nothing changes [read, new business objectives will not be achieved]". Regularly assessing the rewards that motivate employees is therefore of vital importance to all business firms.

\section{REFERENCES}

Alfred, M. (1991). A view from the other side. Productivity SA, 17(3), pp. 7-11.

Arnolds, C.A. (2006). Motivating blue-collar employees in the manufacturing industry: Human resource managers versus employees. Paper delivered at the International Academy of African Business and Development, Ghana Institute of Management and Public Administration, Accra, Ghana, 2327 May.

Arnolds, C.A. \& Boshoff, C. (2002). Motivational interventions in manufacturing firms: An exploratory investigation of selected firms in the Nelson Mandela Metropole. Paper delivered at the International Economic and Management Sciences Conference, Vaal Triangle Technikon, Vanderbijlpark, South Africa, 16-18 September.

Barrier, M. (1996). Improving worker performance. Nation's Business, 84 (9), pp. 28-31.

Bateman, T.S. \& Snell, S.A. (2007). Management: Leading \& collaborating in a competitive world. Boston: McGraw-Hill.

Birkin, M. (2004). What the experts didn't tell us. Management Today, 20(5), pp. 17-18.

Bratton, J. \& Gold, J. (2003). Human resource management: Theory and practice. New York: Palgrave MacMillan.

Burton, L. (2001). Managing motivation. People Dynamics, 19(7), pp. 12-17.

Certo, S.C. (2003). Modern management. Upper Saddle River, New Jersey: Prentice -Hall.

Cohen, J. (1988). Statistical power analysis for the behavioral sciences. Hilldale, New Jersey: Earbaum.

Collis, J. \& Hussey, R. (2003). Business Research. New York: Palgrave MacMillan.

Daft, R.L. (2006). The new era of management. Mason, Ohio: Thomson South-Western.

Daft, R.L. \& Marcic, D. (2007). Management: The new workplace. Mason, Ohio: Thomson South-Western.

Delany, K. \& Turvey, S. (2004). Competing in the race for talent. People Dynamics, 22(1), pp. 29-31.

De Leiburne, D. (1991). In-company crèches set to take off. Human Resources Management, 7(2), p. 39.

Dixon, P. (2004). Motivation - The reason for the crisis: How to motivate people to make

things happen. Retrieved March 10, 2005, from the World Wide Web: http://www.globalchange.com/motivation.htm.

DuBrin, A.J. (1997). Essentials of management. Mason, Ohio: South-Western.

Ellis, L. \& Pennington, S. (2004). Should leaders have tusks or fangs? Management Today, 20(9), pp. 32-33.

Frane, J., Jennrich, R.I. \& Sampson, P.F. 1990. P4M-Factor Analysis. In Dixon, W.J. and Brown, M.B. (eds.): BMDP Statistical Software Manual, (1), pp. 311-337. Barkeley: University of California.
Freemantle, D. (2004). The Buzz: 50 little things that make a big difference to delivering world-class service. London: Nicholas Brealey Publishing. Gainsharing. (1997). Productivity SA, July/August, pp. 8-9.

George, J.M. \& Jones, G.R. (2006). Contemporary management: Creating value in organizations. Boston: McGraw-Hill.

Glassock, S. \& Gram, K. (1995). Winning ways: Establishing an effective workplace recognition system. National Productivity Review, 14(3), pp. 91 -102.

Grimes, C.F. (2005). Employee motivation in the workplace. Retrieved March 13, 2005, from the World Wide Web: http// www.acccel-team.com/motivation/index.html.

Groenewald, A. (2004). Profitable leaders: Seven traps that can bring them down. Management Today, 20(9), pp. 18-19.

Hackman, J.R. \& Oldham, G.R. (1980). Work redesign. Reading. Massachusetts: Addison-Wesley.

Hellriegel, D., Jackson, S.E., Slocum, J., Staudé, G., Amos, T., Klopper, H.B., Louw, L. \& Oosthuizen, T. (2004). Management. Cape Town, South Africa: Oxford University Press.

Hellriegel, D., Slocum, J.W. \& Woodman, R.W. (2001). Organizational behavior. Cincinnati, Ohio: South Western.

Hong, J.C., Yang, S.D., Wang, L.G., Chiou, E.F., Sun, F.Y. \& Huang, T.L. (1995).

Impact of employee benefits on work motivation and productivity. International Journal of Career Management, 7(6), pp. 10-14.

How can you increase employee motivation? (2005). Retrieved September 4, 2006, from the World Wide Web: http://www. bizhelp24.com/index.php?option-com_content\&task=view\& id=742Itemd $=134$.

Igalens, J. \& Roussel, P. (1999). A study of the relationship between compensation package, work motivation and job satisfaction. Journal of Organizational Behavior, 20, pp. 10031025.

Kauermann, G. \& Ortlieb, R. (2004). Temporal pattern in the number of staff on sick leave: The effect of downsizing. Journal of the Royal Statistical Society, Series C - Applied Statistics, 53, pp. 353-367.

Kemp, N. (2002). People need TLC. People Dynamics, 20(8), pp. 24-27.

Lewis, P.S., Goodman, S.H. \& Fandt, P.M. (2004). Management: Challenges for tomorrow's leaders. Mason, Ohio: Thomson South-Western.

Likert, R. (1961). New patterns of management. New York: McGraw-Hill.

Listening to music increases productivity. (2005). Retrieved October 2, 2006, from the World Wide Web: http://www.kutchkacom/ products/musicincreasesproductivity.htm.

Luthans, F. (1998). Organizational behavior. Singapore: McGrawHill.

Malherbe, M.D. \& Pearse, N.J. (2003). The relationship between job enrichment, job satisfaction and service quality: An exploratory study in the retail industry of South Africa. Management Dynamics, 12(2), pp. 2-12.

May, D.R., Gilson, R.L. \& Harter, L.M. (2004). The psychological conditions of meaningfulness, safety and availability and the engagement of the human spirit at work. Journal of Occupational and Organizational Psychology, 77: pp. 11-37.

McFarlin, D. (2000). Motivating employees is not a one-time deal. Retrieved March 13, 2005, from the World Wide Web: http:// www.bizjournals.comdayton/stories/2000/09/04/smallb3. html.

MS-Excel. (2003). Microsoft Corporation. Redmond, United States of America.

Nunnally, J. (1978). Psychometric theory. New York: McGraw-Hill.

People really do make the difference. (2000). Business Times, Sunday Times, 4 June, p. 1.

Ross, S. 2001. Workers turn off autopilot and take charge on assembly lines of the $21^{\text {st }}$ century. Globe and Mail, 3 September, p. B12.

Rothbard, N.P. (2001). Enriching or depleting? The dynamics of engagement in work and family roles. Administrative Science Quarterly, 46: pp. 655-684. 
Salaries not the only draw card. (2002). Sunday Times, Business Times, 26 March, p. 2.

Samodien, N. (2004). Recognizing the role of reward practitioners. People Dynamics, 22(6), pp. 18-19.

Seigel, A.L. \& Ruh, R.A. (1973). Job involvement, participation in decision making, personal background and job behaviour. Organizational Behavior and Human Performance, 9, pp. 318-327.

Sherrat, J. (2000). Attracting and retaining the right staff. Management Today, 6(5), pp. 38-39.

Shives, G. \& Scott, K. (2003). Gainsharing and EVA: The U.S. Postal Service experience. World at Work Journal, 1(January), p. 23.

Shorter week increases French labour efficiency. (2002). Sunday Times, Business Times, 14 July, p. 2.

Smith, C.S. \& Tisak, J. (1993). Discrepancy measures of role stress revisited: New perspectives on old issues. Organizational Behavior and Human Decision Processes, 56, pp. 258-307.

Stajkovic, A.D \& Luthans, F. (2001). Differential effects of incentive motivators on work performance. Academy of Management Journal, 44, pp. 580-590.
Struwig, F.W. \& Stead, G.B. (2001). Planning, designing and reporting research. Cape Town: Pearson Education.

Thompson, A.A., Strickland, A.J \& Gamble, J.E. (2005). Crafting and executing strategy: The quest for competitive advantage. New York: MacGraw-Hill Irwin.

Tiglao-Torres, A. (1990). Work motivation and productivity of government workers. Phillipine Journal of Psychology, 23: pp. 30-38.

Van Zyl, J. (2000). Uncertainty chases people away. Finance Week, 15 September, p. 37.

Vroom, V.H. (1964). Work and motivation. New York: John Wiley $\&$ Sons.

Wah, L. (1999). Value your contingent workforce. Management Review, January, p.6.

Why money is not a motivator. (2004). Retrieved April 26, 2005, from the World Wide Web: http://www.managing. ca/newsletter/2004/newsletter-August18.html.

Workplace changes employees want to see. (1999). Management Review, January, p. 6

\section{ANNEXURE A: QUESTIONNAIRE ITEMS}

\section{FINANCIAL REWARDS}

FINAN1 Wage increases

FINAN2 Cash incentives (bonuses, commissions)

FINAN3 Stock option plans

FINAN4 Gainsharing plans

FINAN5 Profit-sharing

FINAN6 Medical and dental cover

FINAN7 Disability insurance

FINAN8 Retirement savings plan

FINAN9 Child-care

\section{CONSUMABLE REWARDS}

CONSU1 Coffee break treats

CONSU2 Free/ subsidised lunches

CONSU3 Dinners for family paid for by firm

CONSU4 Company picnics

CONSU5 After-work cheese and wine parties

\section{SOCIAL REWARDS}

SOCIA1 Management greeting in friendly manner

SOCIA2 Formal recognition (diplomas, congratulatory cards and letters)

SOCIA3 Management asking my advice

SOCIA4 Management complimenting me on work progress

SOCIA5 Recognising my performance in newsletter or bulletin of firm

SOCIA6 Verbal praise (pat on the back)

\section{JOB DESIGN REWARDS}

JOBDE1 Job with more responsibility

JOBDE2 Job rotation

JOBDE3 Autonomy to schedule my own work

JOBDE4 Management allowing me to determine my own clock-in and clock-out times

JOBDE5 Management allowing me to determine my own lunch and tea breaks

JOBDE6 Employee involvement programmes (work committees, board representation, quality circles)

JOBDE7 Setting my own objectives together with management (MBO)

JOBDE8 Clear career plan and career development

JOBDE9 Job security

\section{MANIPULATABLE REWARDS}

MANIP1 Company cars

MANIP2 Watches, rings or tie pins

MANIP3 Commendations (recommending for promotion and other employment)

MANIP4 Use of company recreation/ convenience facilities for personal projects

MANIP5 On-site fitness services

MANIP6 Clothing (uniform of firm)

FINAN17 Public transport passes
FINAN10 Elder-care

FINAN11 Educational support

Parental leave

14 Paid holidays

FINAN16 Private use of firm's telephone

FINAN18 Expense accounts ((buying services from firm on account)

VISUAL AND AUDITORY REWARDS

VISUA1 Piped-in music at my work station

VISUA2 Free company literature 